\title{
Involvement of Excitatory Amino Acids in Neurotransmission of Inspiratory Drive to Spinal Respiratory Motoneurons
}

\author{
Donald R. McCrimmon, ${ }^{1,2}$ Jeffrey C. Smith, ${ }^{1,3}$ and Jack L. Feldman ${ }^{1-3}$ \\ Departments of 'Physiology and 'Anesthesia, Northwestern University Medical School, Chicago, Illinois 60611, and \\ ${ }^{3}$ Systems Neurobiology Laboratory, Department of Kinesiology, University of California Los Angeles, Los Angeles, \\ California 90024
}

The role of excitatory amino acids in the transmission of bulbospinal respiratory drive to spinal motoneurons was investigated in the in vitro and in vivo spinal cord of the rat. In vitro studies were performed with a preparation of neonatal rat brain stem and spinal cord that spontaneously generates rhythmic respiratory drive to spinal respiratory motoneurons. This in vitro system allowed examination of the effects of pharmacological agents on spinal motoneuron activity, without perturbing the activity of bulbospinal neurons transmitting the respiratory drive. The amplitude of spontaneous motor discharge in spinal ventral roots containing phrenic and intercostal motor axons was reduced in a dosedependent manner by antagonists to excitatory amino acids acting at NMDA receptors [D,L-2-amino-5-phosphonovaleric acid (D,L-AP5)] and non-NMDA receptors [kynurenic acid, $\gamma$-D-glutamylglycine, $\gamma$-D-glutamyltaurine, and $L-$ and $D, L-2$ amino-4-phosphonobutyric acid (L-AP4, D,L-AP4)]. The order of potency of the antagonists for complete block of the motor output was L-AP4 $>$ D,L-AP4 $>$ kynurenic acid $>\gamma$-D-glutamylglycine $>$ D,L-AP5 $\geq \gamma-D$-glutamyltaurine. Amino acid uptake inhibitors augmented the spontaneous motoneuron activity, further confirming the involvement of endogenous excitatory amino acids in transmission of respiratory drive. The results obtained in vitro with AP4, kynurenic acid, and amino acid uptake inhibitors were confirmed in vivo by bathing segments of the rat spinal cord in situ with solutions containing antagonists and uptake inhibitors. The present results suggest that an important component of the neurotransmission of bulbospinal respiratory drive involves endogenous excitatory amino acids acting at AP4-sensitive sites and other non-NMDA (quisqualate/kainate) receptors. The bulbospinal-spinal respiratory motoneuron synapse may provide a convenient model synapse in the spinal cord for detailed analysis of mechanisms underlying excitatory amino acid-mediated synaptic transmission of motor drive.

Coordinated respiratory movements of the diaphragm and chest wall in mammals are generated by periodic bursts of impulse activity in phrenic and intercostal motoneurons. These bursts

\footnotetext{
Received May 20, 1988; revised Oct. 11, 1988; accepted Nov. 30, 1988.

We would like to thank Drs. Ann C. Bonham and Howard H. Ellenberger for help in several experiments and Drs. Guosong Liu and N. Traverse Slater for helpful comments on the manuscript. This work was supported by NIH Grants HL-37941 and NS-24742. J.C.S. is a Parker B. Francis Foundation Fellow.

Correspondence should be addressed to Professor Jack L. Feldman, Department of Kinesiology, University of California, Los Angeles, 405 Hilgard Avenue, Los Angeles, CA 90024-1586.

Copyright (C) 1989 Society for Neuroscience $0270-6474 / 89 / 061910-12 \$ 02.00 / 0$
}

result from respiratory-rhythmic inputs from bulbospinal neurons with cell somas concentrated in the medulla in the regions of the ventrolateral nucleus of the tractus solitarius (dorsal respiratory group) and the nucleus ambiguus-retroambigualis (ventral respiratory group) (see Feldman, 1986). Both electrophysiological (Cohen et al., 1974; Hilaire and Monteau, 1976; Feldman and Speck, 1983; Lipski et al., 1983; Davies et al., 1985a, b; Duffin and Lipski, 1987) and neuroanatomical tracttracing (Loewy and Burton, 1978; Feldman et al., 1985; Ellenberger and Feldman, 1988) studies suggest that a major component of the pathway for transmission of the bulbospinal respiratory drive to phrenic and intercostal motoneurons is monosynaptic. However, while there is some information on the distribution of synaptic inputs of descending bulbospinal axons to spinal respiratory motoneuron pools and on electrophysiological properties of respiratory motoneurons, there is currently little information on the synaptic mechanisms involved in excitatory transmission of respiratory drive.

The identity of the neurotransmitter(s) mediating transmission of excitatory drive at the bulbospinal respiratory neuronspinal respiratory motoneuron synapse is not known. Certain acidic amino acids, especially glutamate and aspartate, have been implicated as transmitters at excitatory synapses in the vertebrate CNS (Mayer and Westbrook, 1987), including excitatory synapses on vertebrate spinal motoneurons (Dale and Roberts, 1984; Dale and Griliner, 1986). They also play a fundamental role in rhythmic motor (locomotor) pattern generation in the lower vertebrate (Dale and Roberts, 1984; Brodin and Grillner, 1985; Dale, 1986; Wallén and Grillner, 1987) and mammalian spinal cord (Smith and Feldman, 1987a; Smith et al., 1988d, b). Furthermore, excitatory postsynaptic potentials in respiratory motoneurons evoked by bulbospinal respiratory pathways (Fedorko et al., 1983; Lipski et al., 1983; Duffin and Lipski, 1987) have temporal characteristics consistent with fast excitatory neurotransmission. Excitatory amino acids are therefore reasonable candidates as neurotransmitters mediating excitatory synaptic drive to spinal respiratory motoneurons.

This study was undertaken to determine if activation of excitatory amino acid receptors by endogenous ligands is an important determinant of phrenic and intercostal motoneuronal activity. Our initial experiments (McCrimmon et al., 1986a, b) indicated that these receptors are involved in an important way, and we have attempted to characterize the receptor subtypes mediating these effects. Pharmacological characterization required that we distinguish among several classes of receptors, based on their relative sensitivity to kainic acid, quisqualic acid, or $N$-methyl-D-aspartic acid (NMDA) and associated antago- 
nists (Watkins and Evans, 1981; Mayer and Westbrook, 1987; Stone and Burton, 1988). For example, D,L-2-amino-5-phosphonovaleric acid (D,L-AP5) is a highly selective antagonist for the NMDA receptor subtype, while the dipeptide $\gamma$-D-glutamylglycine (DGG) is approximately 70-100 times more potent as an antagonist at kainate and quisqualate receptors (Jones et al., 1984) and only 10 times less effective than D-AP5 at NMDA receptors. Kynurenic acid is a competitive antagonist with greatest potency at NMDA receptors, but it also acts at kainic acid and quisqualic acid receptors at higher concentrations (Ganong et al., 1983; Stone and Connick, 1985; Mayer and Westbrook, 1987; Stone and Burton, 1988). Recently, an additional receptor class has been postulated, distinguished by a requirement for $\mathrm{Cl}^{-}$and $\mathrm{Ca}^{2+}$ ions and stereoselective sensitivity to the antagonist L-2-amino-4-phosphonobutyric acid (L-AP4; Foster and Fagg, 1984). A role for these latter receptors in synaptic transmission is suggested by the AP4 blockade of synaptic transmission of entorhinal projections to hippocampal granule cells (Koerner and Cotman, 1981), lateral olfactory tract projections to prepyriform cortex neurons (Collins, 1982; Hori et al., 1982; ffrench-Mullen et al., 1985), projections of hippocampal granule cells to CA3 pyramidal neurons (Yamamoto et al., 1983; Robinson et al., 1984; Cotman et al., 1986), and projections to spinal cord dorsal horn neurons (Davies and Watkins, 1982; Evans et al., 1982). In the present studies, we found that the AP4 receptor subtype, as well as other non-NMDA receptors, play an important role in the control of respiratory motoneuronal discharge in the spinal cord.

Preliminary reports of this work have appeared in abstract form (McCrimmon et al., 1986a, b; McCrimmon and Feldman, 1987).

\section{Materials and Methods}

Studies were conducted both in vitro and in vivo using neonatal and juvenile rats, respectively. For in vitro studies, the brain stem and spinal cord, extending from the rostral pons or pontomedullary junction down to the lumbosacral spinal cord, were isolated from 0 - to 4-d-old SpragueDawley rats. The procedures for isolation of the neonatal rat brain stem and spinal cord and details of the brain stem-spinal cord preparation have been described previously (Smith and Feldman, 1985, 1987a, b; see also Suzue, 1984). Decerebration was performed under ether anesthesia, and the neuraxis was isolated by dissection in the control bathing solution containing (in $\mathrm{mm}$ ) $128 \mathrm{NaCl}, 3.0 \mathrm{KCl}, 1.5 \mathrm{CaCl}_{2}, 1.0$ $\mathrm{MgSO}_{4}, 21 \mathrm{NaHCO}_{3}, 0.5 \mathrm{NaH}_{2} \mathrm{PO}_{4}$, and $30 \mathrm{D}$-glucose equilibrated with $95 \% \mathrm{O}_{2}-5 \% \mathrm{CO}_{2}(\mathrm{pH} 7.4)$ at $27^{\circ} \mathrm{C}$. The cerebellum was removed, the isolated brain stem-spinal cord was pinned down, ventral surface upwards, on Sylgard resin in a recording chamber (Fig. 1), and the preparation was continuously bathed in the control solution. For some experiments, the $\mathrm{MgSO}_{4}$ concentration in the bathing solution was increased to 5 or $10 \mathrm{~mm}$ and reduced to $0 \mathrm{~mm}$ in several other experiments; isotonicity of the solutions was maintained by equimolar adjustments of the $\mathrm{NaCl}$ concentration. The in vitro bath was partitioned into 2 compartments by a transverse vaseline barrier across the neuraxis. The partition was placed either at the spinomedullary junction, permitting independent control of the composition of solutions bathing the brain stem and spinal cord (Fig. 1) or at the cervicothoracic junction for independent control of the solutions bathing the brain stem-cervical spinal cord and the thoracolumbar cord. Respiratory motoneuronal discharges were recorded by amplifying and filtering $(0.1-10 \mathrm{kHz}) \mathrm{sig}$ nals from suction electrodes applied to cranial (glossopharyngeal or vagus) nerve roots, cervical $\left(\mathrm{C}_{4}\right.$ or $\left.\mathrm{C}_{5}\right)$ ventral roots containing phrenic motoneuronal axons, and thoracic ventral roots $\left(T_{1}, T_{2}, T_{4}, T_{6}\right.$, or $\left.T_{8}\right)$ containing intercostal motoneuron axons. The recorded signals were integrated with a low-pass filter (paynter filter, time constant $=13 \mathrm{msec}$ ) for analysis of the motor discharge pattern.

In vivo studies were conducted on juvenile (20-50 gm) Sprague-Dawley rats anesthetized with ketamine-xylazine $(40$ and $60 \mathrm{mg} / \mathrm{kg}$, i.p., respectively, and supplemented as required). The diaphragm was ex-

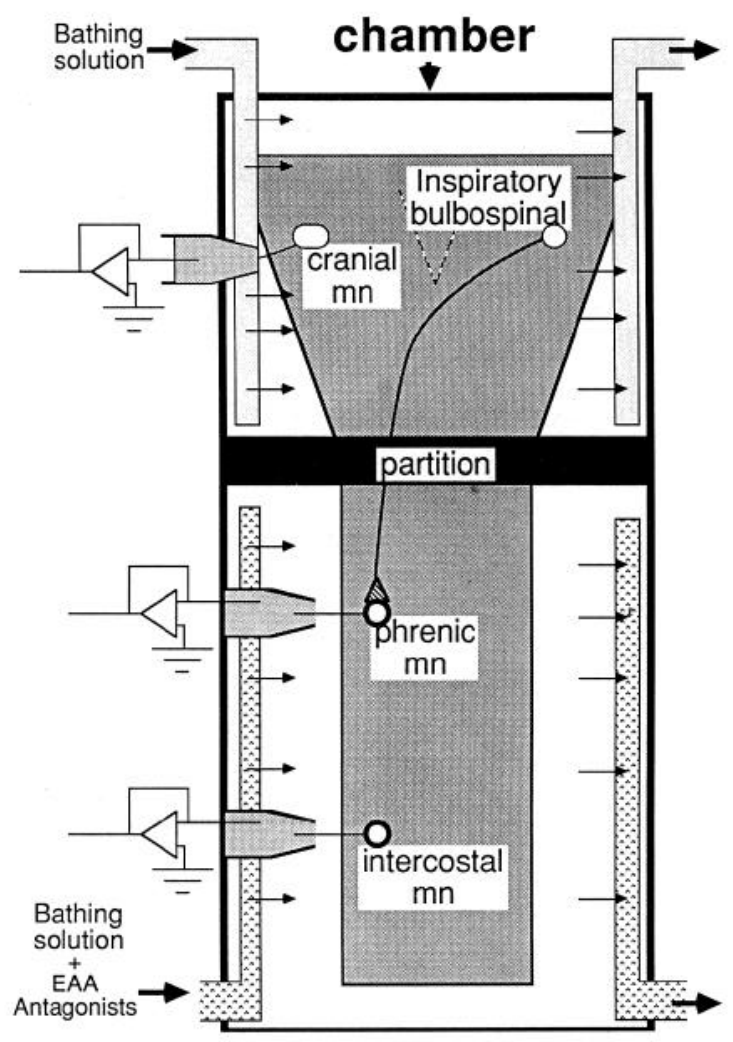

Figure 1. Schematic diagram of recording chamber with isolated brain stem-spinal cord. A bath partition at the spinomedullary junction separating solutions bathing brain stem and spinal cord is shown. Partitions were also constructed at the $C_{3}$ or $T_{1}$ levels for certain experiments; see text for further explanation.

posed through an incision along the caudal edge of the rib cage, the liver was retracted, and bipolar silver wire electrodes were inserted into the diaphragm for recording EMG. The rat was placed in a head holder, and a laminectomy was performed to expose the spinal cord from the $\mathrm{T}_{5}-\mathrm{T}_{12}$ segments. The dura was opened, and a small-diameter cannula (PE-10 stretched to reduce its outer diameter) was placed under the cord, with the tip placed proximal to the segment from which intercostal nerve activity was recorded. An external intercostal nerve was exposed for $5-10 \mathrm{~mm}$ from its bifurcation from the internal nerve after removing the overlying superficial intercostal muscle. The nerve was cut distally and mounted on a fine bipolar silver wire electrode. The rib cage was stabilized by suturing the superficial muscles (along the spinal column, rostral and caudal to the laminectomy) to clamps and by using a metal plate to exert a constant downward force on the ribs in the immediate vicinity of the recorded nerve. Thoracic spinal segments were bathed in a physiological solution (buffered saline, $\mathrm{pH} 7.4$ ), containing excitatory amino acid receptor or other neurotransmitter receptor antagonists, by perfusing the bathing solution through the cannula inserted under the ventral cord. The size of the juvenile animals used for these studies was chosen so that the spinal cord thickness and associated diffusion distances were sufficiently small to allow adequate tissue concentrations of antagonists to be attained for block of motoneuronal discharge.

Pharmacological agents added to the in vivo and in vitro bathing solutions included: L-glutamic acid (Sigma), kainic acid (Sigma), kynurenic acid (Sigma), $\gamma$-D-glutamylglycine (DGG; Sigma), $\gamma$-D-glutamyltaurine (DGT; Tocris Neuramin), L-2-amino-4-phosphonobutyric acid (L-AP4; Tocris Neuramin), D,L-2-amino-4-phosphonobutyric acid (D,L-AP4; Sigma), D,L-2-amino-5-phosphonovaleric acid (D,L-AP5; Sigma), $N$-acetyl-aspartyl-glutamate (Bachem), amino acid uptake inhibitors dihydrokainic acid (Sigma) or glutamate monohydroxamate (Sigma), atropine sulfate (Sigma), and $d$-tubocurarine (Sigma). All pharmacological agents were dissolved in the physiological bathing solution ( $\mathrm{pH}$ adjusted to 7.4 ) before application to the in vitro bath or in vivo spinal cord. 

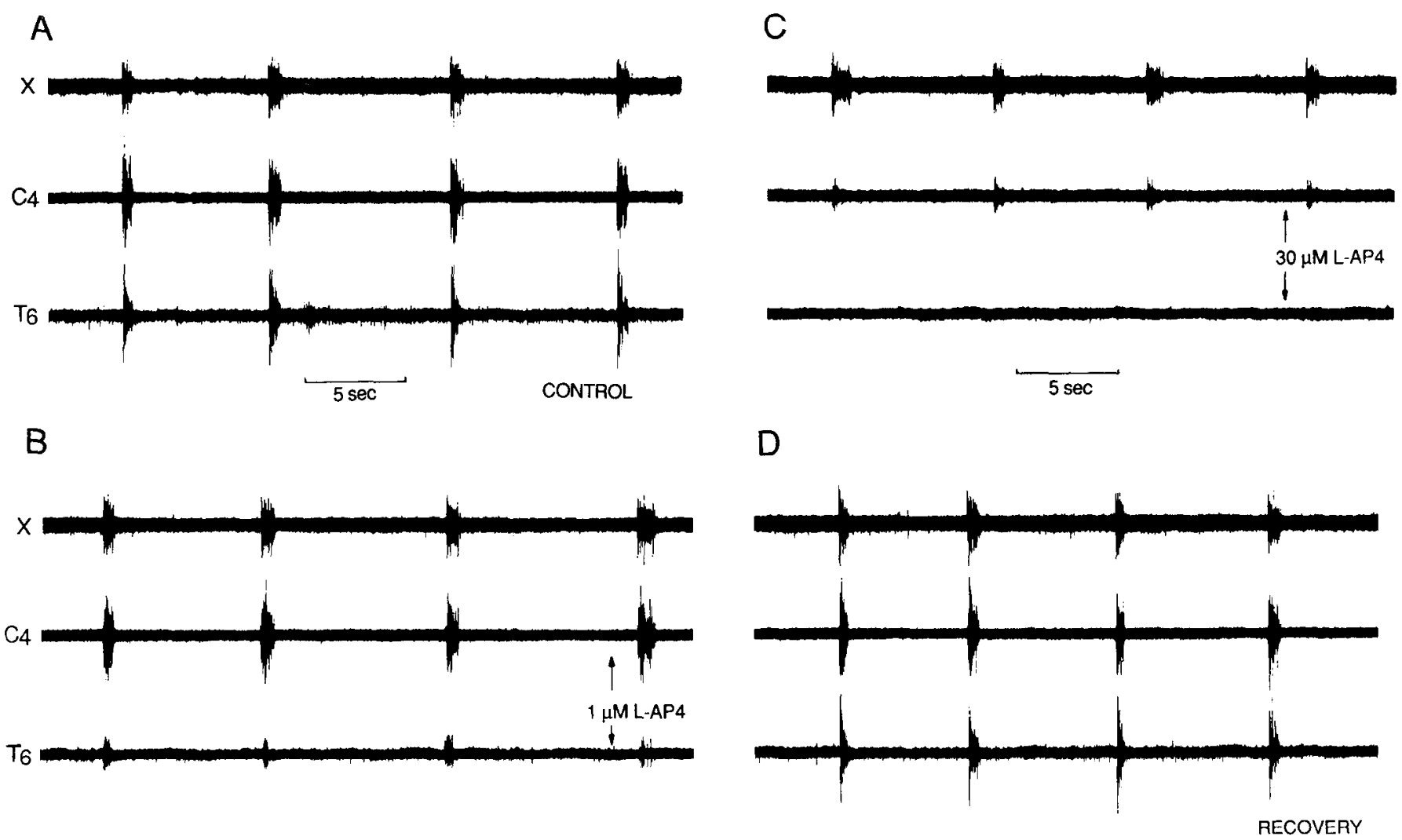

Figure 2. Inhibition of spinal respiratory motor discharge by L-2-amino-4-phosphonobutyric acid (L-AP4) applied to neonatal rat spinal cord in vitro. Traces in each panel show the respiratory motoneuronal discharge recorded from the vagus nerve $(X)$, $\mathrm{C}_{4}$ cervical, and $\mathrm{T}_{6}$ thoracic ventral roots. $A$, Control pattern of motor activity. $B$ and $C$, Steady-state motor discharge pattern after application of 1 and $30 \mu \mathrm{M}$ L-AP4, respectively, to solution bathing spinal cord. In vitro bath was partitioned at the spinomedullary junction to separate the solutions bathing the spinal cord and brain stem. Maintenance of rhythmic respiratory drive during block of spinal motoneuron discharge is indicated by maintenance of rhythmic motor activity on cranial nerve. Note the greater potency of antagonist in blocking thoracic motoneuron activity. $D$, Recovery of motoneuronal activity $15 \mathrm{~min}$ following washout of antagonist.

\section{Results}

\section{In Vitro Studies}

Spontaneous respiratory motoneuronal discharge was recorded from $\mathrm{C}_{4}$ and $\mathrm{C}_{5}$ and thoracic ventral roots as well as cranial nerve roots (Suzue, 1984; Smith and Feldman, 1987a, b; Figs. 2-4). This periodic discharge occurred at a frequency of 5-12/ min. Each burst consisted of a rapidly peaking then decrementing discharge envelope (400-700 msec duration; Figs. 25). Effects of the excitatory amino acid receptor agonists and antagonists on the motor output were assessed by analysis of effects on the peak amplitude and duration of the discharge envelope obtained by integrating the recorded nerve discharge.

\section{Excitatory amino acid antagonists}

With the in vitro bath partitioned at the spinomedullary junction (Fig. 1), application of the excitatory amino acid antagonists (LAP4, D,L-AP4, kynurenic acid, D,L-AP5, DGG, or DGT) to the solution bathing the spinal cord (with control solution bathing the brain stem) caused a reversible, dose-dependent decrease of the amplitude and duration of the integrated phrenic and intercostal motoneuronal discharge with ultimate abolition of the motor nerve output (Figs. 2, 3, 5). When the partition was placed at the level of the upper thoracic segments (so that both phrenic motoneurons and brain-stem neurons remained bathed in con- trol solution), the intercostal respiratory motor discharge was rcduced in a dose-dependent manner (c.g., Fig. 4) and ultimatcly abolished, without perturbation of the phrenic or cranial motoneuronal discharge. Perturbations of the spinal motor discharge typically occurred within 2-4 min following bath application of the antagonists. In all cases, the amplitude of the integrated cranial nerve discharge remained unchanged during application of the antagonists (Figs. 2-4), indicating that the level of respiratory drive to motoneuronal pools was maintained. Maintenance of bulbospinal rhythmic respiratory drive during block of spinal motoneuron activity was confirmed in preparations with bath partitions at the thoracic level (Fig. 4) and by intracellular recording from phrenic motoneurons, which show maintenance of subthreshold rhythmic motoneuron drive potentials but block of spike discharge (Smith et al., 1988a, b; see Discussion). The antagonist effects were reversible in all cases; complete restoration of the spinal motoneuron discharge usually occurred within 10-12 min following washout of antagonist-containing solutions.

The dose-effect relationships for the excitatory amino acid antagonists are summarized in Figure 6. The discharge amplitudes were analyzed after $10-15$ min equilibration times at each antagonist concentration; 10-20 consecutive integrated discharges were averaged from each brain stem-spinal cord preparation at each concentration, and the average peak amplitudes 
of the integrated nerve activities were pooled. In a given preparation, the percentage reduction in the thoracic motoneuronal discharge was always larger at a given antagonist concentration than the cervical motoneuronal discharge (Figs. 2, 3); dose-effect relationships for cervical and thoracic motoneuron pools were therefore analyzed separately. The dose dependency of antagonist effects for each of the cervical (phrenic) motoneuron pools studied $\left(\mathrm{C}_{4}\right.$ and $\left.\mathrm{C}_{5}\right)$ was similar, and the data from these motoneuron populations were pooled (Fig. $6 \mathrm{~A}$ ). The sensitivity of each of the thoracic motoneuron pools studied $\left(T_{1}, T_{2}, T_{4}, T_{6}\right.$, $T_{8}$ ) to the antagonists was similar, and the data from thoracic motoneuron populations were also pooled (Fig. $6 B$ ).

All of the antagonists applied to the in vitro spinal cord bath produced dose-dependent reductions of the amplitude of the spinal respiratory motoneuronal discharge (Figs. 2-6). In general, the most potent antagonist in blocking the motor discharge at all concentrations was AP4, which was effective at concentrations 2-3 orders of magnitude lower than the other antagonists (Fig. 6). For example, the antagonist concentrations for reduction of the cervical motoneuronal discharge amplitude to $50 \%$ of control $\left(\mathrm{EC}_{50}\right)$ obtained from the dose-effect curves (Fig. 6) were $0.7 \mu \mathrm{M}, 1.6 \mu \mathrm{M}, 177 \mu \mathrm{M}, 890 \mu \mathrm{M}, 1.25 \mathrm{~mm}$, and 2.25 mM for L-AP4, D,L-AP4, KYN, DGG, D,L-AP5, and DGT, respectively; $\mathrm{EC}_{50}$ 's for thoracic motoneuronal pools were $0.5 \mu \mathrm{M}$, $0.7 \mu \mathrm{M}, 158 \mu \mathrm{M}, 416 \mu \mathrm{M}, 700 \mu \mathrm{M}$, and $1.58 \mathrm{mM}$ for L-AP4, D,LAP4, KYN, D,L-AP5, DGT, and DGG, respectively. The higher potency of L-AP4 than the racemic mixture D,L-AP4 suggests a stereoselectivity in the antagonist actions of AP4.

The dose-effect curves in all cases were nonlinear, and in the case of the NMDA receptor antagonist AP5, the curve exhibited an inflection over the intermediate range of concentrations (Fig. 6). As a result, the relative potencies of the non-AP4 antagonists in attenuating the motoneuronal discharge varied as a function of antagonist concentration. At low antagonist concentrations, AP5 exhibited the highest potency of the non-AP4 antagonists in reducing the discharge amplitude; the order of potency of the non-AP4 antagonists at low concentrations was D,L-AP5 $>$ KYN $>$ DGG > DGT. The concentrations for reduction of the cervical motoneuron discharge amplitude to $80 \%$ of control $\left(\mathrm{EC}_{20}\right)$ obtained from the dose-effect curves were $(\mu \mathrm{M}) 40,80,300$, and 560 for D,L-AP5, KYN, DGG, and DGT, respectively; $\mathrm{EC}_{20}$ 's for thoracic motoneuron populations were $30,60,200$, and 500 $\mu \mathrm{M}$ for D,L-AP5, KYN, DGG, and DGT, respectively. Over the range of AP5 concentrations expected for NMDA-receptor selectivity, $<100 \mu \mathrm{M}$ (Mayer and Westbrook, 1987; Stone and Burton, 1988), the amplitude of the cervical and thoracic motor discharge was reduced by $\sim 30 \%$ and $\sim 45 \%$, respectively (Fig. 6). The inflection in the AP5 dose-effect curve occurred over the concentration range $100-300 \mu \mathrm{M}$, with a related reduction in AP5 potency at concentrations $>100 \mu \mathrm{M}$. Accordingly, at high antagonist concentrations, kynurenic acid was the most potent of the non-AP4 antagonists in blocking the motoneuronal discharge; the order of potency of the non-AP4 antagonists for block of the motor output at high antagonist concentrations was $\mathrm{KYN}>\mathrm{DGG}>\mathrm{D}, \mathrm{L}-\mathrm{AP} 5 \geq \mathrm{DGT}$. The antagonist concentrations for reduction of the cervical motoneuron discharge amplitude to $10 \%$ of control $\left(\mathrm{EC}_{90}\right)$ were $(\mathrm{mM}): 0.5,2.25,8.0$, and 8.0 for KYN, DGG, D,L-AP5, and DGT, respectively; $\mathrm{EC}_{90}$ 's for thoracic motoneuronal pools were $0.4,2.0,4.0$, and $8.0 \mathrm{mM}$ for KYN, DGG, D,L-AP5, and DGT, respectively. The block of the spinal motoneuron output at the higher concentrations of kynurenic acid, DGG, and DGT was partially reversed by
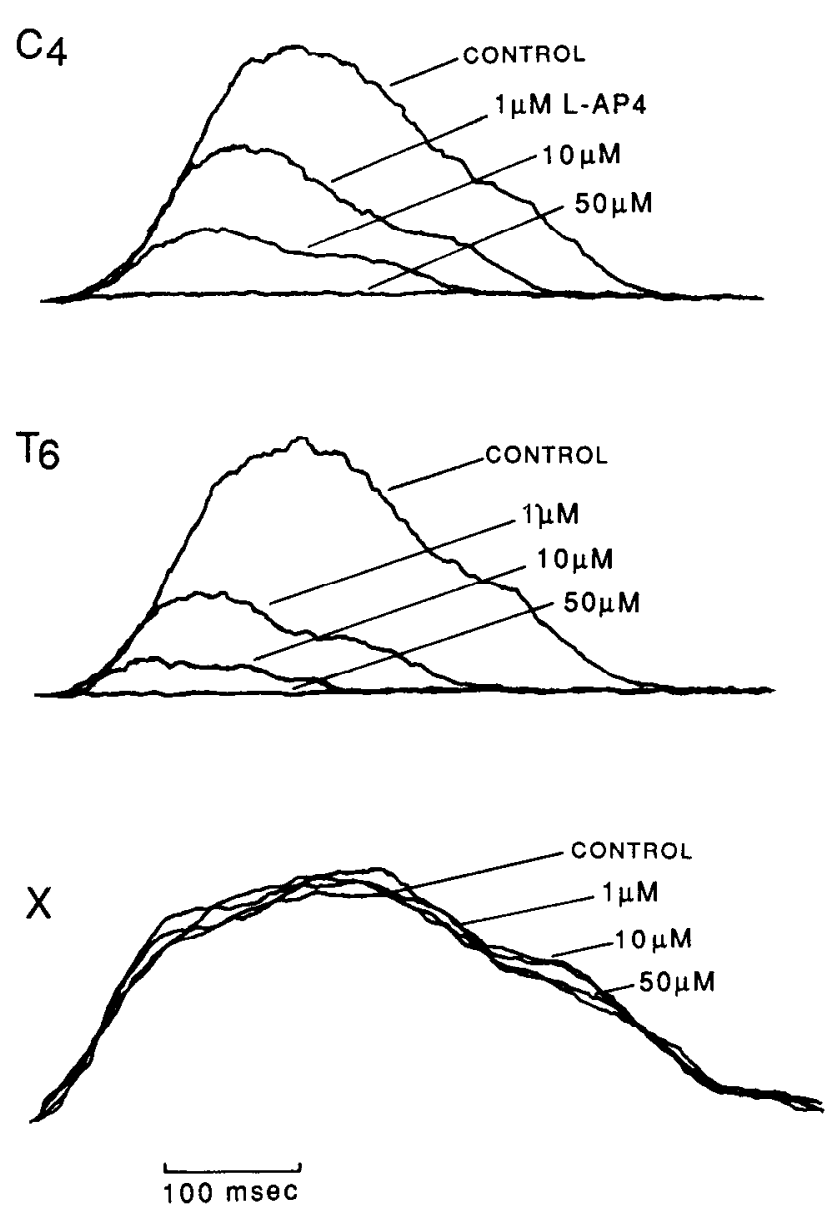

Figure 3. Averaged integrated cranial nerve [vagus $(X)$ ] and spinal $\left(C_{4}\right.$ and $T_{6}$ ) respiratory nerve discharge illustrating dose-dependent reductions in amplitude and duration of spinal nerve discharge in vitro with bath application of 1,10 , and $50 \mu \mathrm{M} \mathrm{L}-\mathrm{AP} 4$. Each trace is the average of 15 successive discharges at each antagonist concentration. Amplitude of cranial nerve discharge is unaffected, indicating maintenance of respiratory drive during antagonist block of spinal motoneuron activity.

bath-application of L-glutamic acid (0.5-1 mM; Fig. 4) or kainic acid (15-30 $\mu \mathrm{M}$; Fig. 5), although complete analysis of doseeffect relationships over the full concentration range in the presence of the excitatory amino acid agonists was not performed. The block of the motor output by AP4 was also partially reversed by bath application of L-glutamic acid (0.5-1 $\mathrm{mm}$ ) or $N$-acetyl-aspartyl-glutamate (4-5 mM) (ffrench-Mullen et al., 1985).

The involvement of NMDA receptors in transmission of excitatory drive was also tested by varying the concentration of $\mathrm{Mg}^{2+}$ in the in vitro spinal cord bath. Elevations of extracellular $\mathrm{Mg}^{2+}$ in the spinal cord bathing solution to 5 or $10 \mathrm{mM} \mathrm{Mg}^{2+}$, which should block NMDA receptors (Mayer and Westbrook, 1987), produced a reduction of the cervical and thoracic motoneuronal discharge. The reduction in peak amplitude of the cervical root discharge was (mean \pm SD) $10 \pm 4 \%$ and $18 \pm$ $5 \%(n=4)$ at 5 and $10 \mathrm{mM} \mathrm{Mg}^{2+}$, respectively; the thoracic motoneuronal activity was more sensitive to elevations of extracellular $\mathrm{Mg}^{2+}$, exhibiting a reduction in discharge amplitude of $18 \pm 7 \%$ and $49 \pm 13 \%(n=4)$ at 5 and $10 \mathrm{mM} \mathrm{Mg}^{2+}$, respectively. Reduction of the $\mathrm{Mg}^{2+}$ in the bathing medium to $0 \mathrm{mM}$, which should relieve endogenous NMDA channel block by $\mathrm{Mg}^{2+}$ at the normal physiological $\mathrm{Mg}^{2+}$ concentrations (1 

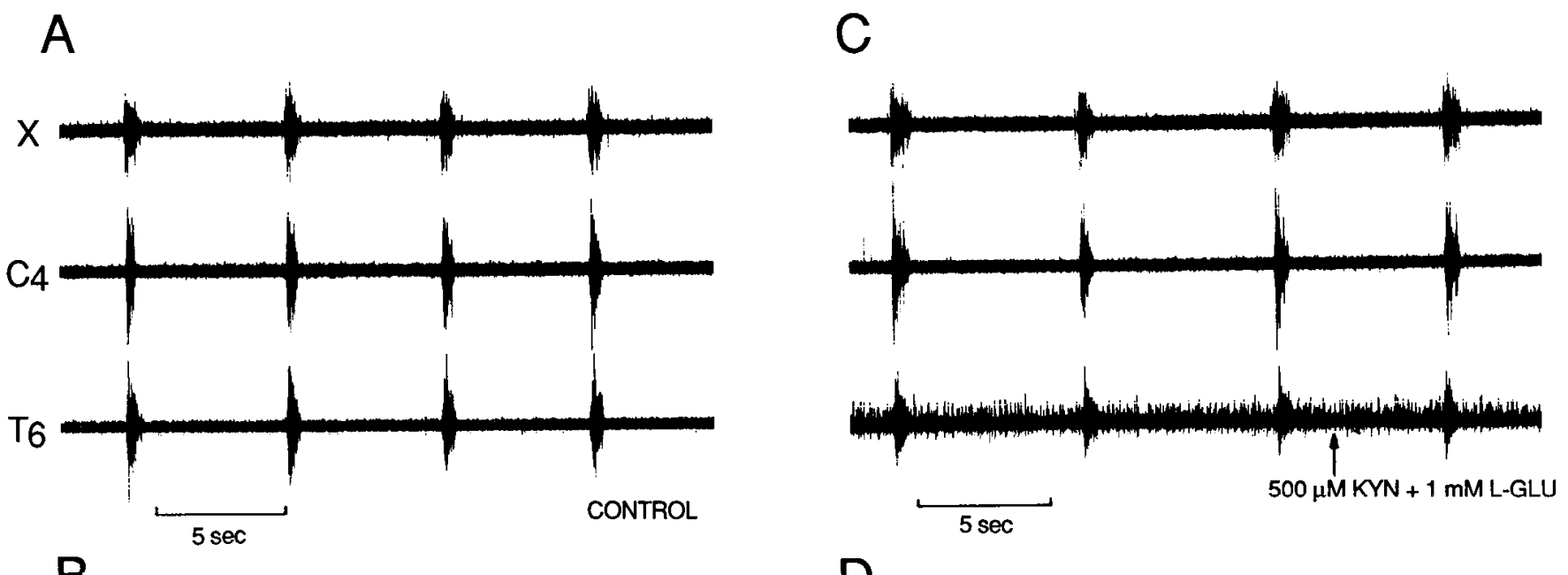

B
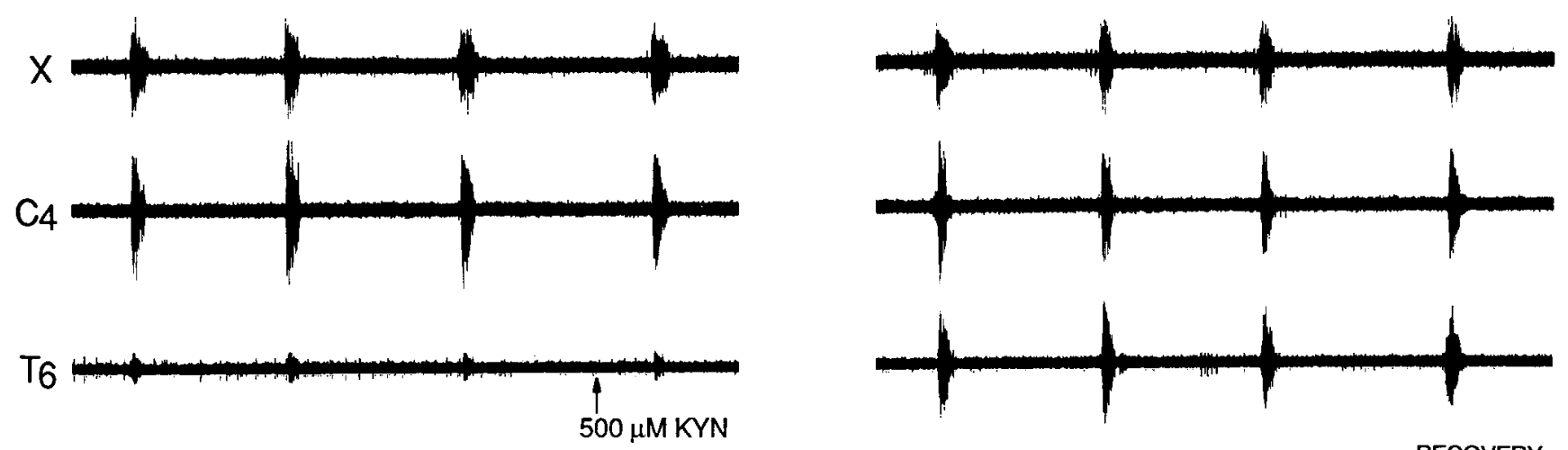

RECOVERY

Figure 4. Inhibition of spinal respiratory motor discharge by kynurenic acid $(K Y N)$ applied to thoracic spinal cord in vitro. In vitro bath was partitioned at the $T_{1}$ level to separate solutions bathing the cervical and thoracic spinal cord. $A$, Control motor discharge on cervical $\left(C_{4}\right)$ and midthoracic $\left(T_{6}\right)$ ventral roots. $B$, Steady-state discharge pattern after application of kynurenic acid $(0.5 \mathrm{~mm})$ to the solution bathing thoracic cord. Note nearly complete block of thoracic motor output at antagonist concentration shown without perturbation of cervical phrenic and cranial motoneuron activity; complete block of thoracic motor output occurred at higher antagonist concentrations. $C$, Partial reversal of antagonism of thoracic motoneuron activity by addition of $1 \mathrm{~mm}$ L-glutamic acid $(L-G L U)$ to the thoracic cord bath. $D$, Recovery of respiratory motor discharge following washout of glutamic acid-kynurenic acid solution.

$\mathrm{mm}$ ) and alter the voltage-dependent behavior of the NMDA channel (Mayer and Westbrook, 1987), did not produce any observable change in the spinal motoneuronal discharge.

\section{Amino acid uptake inhibitors}

Application of solutions containing the amino acid uptake inhibitor dihydrokainic acid (DIIK) (Watkins and Evans, 1981) to the in vitro spinal cord bath induced tonic motoneuronal discharge and caused an augmentation of the spontaneous cervical and thoracic motoneuron discharge (Fig. 7). The increase in peak amplitude of the integrated cervical and thoracic discharge at $1 \mathrm{mM} \mathrm{DHK}$ was (mean $\pm \mathrm{SD}) 30 \pm 4 \%(n=4)$ and $51 \pm 5 \%(n=4)$, respectively.

\section{Cholinergic antagonists}

Antagonists of cholinergic muscarinic (atropine sulfate) or nicotinic ( $d$-tubocurarine) neurotransmission were ineffective in altering the spinal motoneuron discharge at concentrations up to $100 \mu \mathrm{M}$, higher than concentrations required for block of nicotinic and muscarinic receptors in other systems (Colquhoun et al., 1979; Halliwell and Adams, 1982; ffrench-Mullen et al., 1983; Slater et al., 1986). That this block of another potentia? excitatory neurotransmitter system does not block the spinal motoneuronal output, provides additional confirmation of the functional specificity of the perturbations induced by blocking the excitatory amino acid receptors.

\section{In Vivo studies}

Spontancous respiratory discharge could be reliably obtained from the external intercostal nerves in midthoracic $\left(\mathrm{T}_{5}-\mathrm{T}_{8}\right)$ regions of anesthetized, juvenile rats (Figs. 8, 9). Only rarely could respiratory discharge be recorded from more caudal segments when the animal was spontaneously breathing room air or $100 \%$ $\mathrm{O}_{2}$, although an inspiratory discharge pattern could be induced on caudal segments by increasing respiratory drive by giving the animal an inspired gas mixture of $5 \% \mathrm{CO}_{2}-95 \% \mathrm{O}_{2}$.

Application of bathing solutions containing either kynurenic acid (10 mM) or D,L-AP4 (10 mM; Fig. 8), but not atropine sulfate $(100 \mu \mathrm{M})$ or $d$-tubocurarine $(100 \mu \mathrm{M})$, to the ventral surface of the thoracic spinal cord in situ abolished respiratory motoneuronal discharge on the external intercostal nerve. Increasing the respiratory drive by giving the animal $5 \% \mathrm{CO}_{2}-$ $95 \% \mathrm{O}_{2}$ to breathe did not restore the respiratory activity during the period of application of AP4 or kynurenic acid. In most 
experiments, washing the thoracic cord with physiological saline led to rapid recovery of spontaneous respiratory discharge. If washing began immediately upon cessation of the intercostal nerve discharge, the amplitude of the integrated diaphragm EMG was either unaffected or increased. The increase was presumably a homeostatic compensation for the reduced ventilation and associated increase in arterial $\mathrm{PCO}_{2}$ resulting from decreased intercostal muscle activity. In 4 expcriments in which the washout of the antagonists was not begun immediately, diaphragm EMG activity ceased several minutes after the cessation of intercostal nerve discharge, presumably due to diffusion of the antagonist-containing solution to cervical spinal levels. In 3 experiments, application of solutions containing the amino acid uptake inhibitors aspartate- or glutamate-monohydroxamate (10 mM; Fig. 9), markedly increased the peak amplitude of the intercostal nerve inspiratory discharge and induced tonic activity during the expiratory phase.

\section{Discussion}

The present results indicate that perturbations affecting excitatory amino acid receptors within the spinal cord can powerfully affect transmission of bulbospinal inspiratory drive to phrenic and intercostal motoneurons. The block of spontaneously occurring inspiratory motoneuronal discharge by antagonists of excitatory amino acid neurotransmission, and the potentiation of respiratory motor discharge by inhibitors of amino acid uptake both in vivo and in vitro, suggests that excitatory amino acids released endogenously in the spinal cord are involved in bulbospinal transmission of inspiratory drive.

The different potencies of the various antagonists in blocking the motor discharge suggest that specific excitatory amino acid receptor subtypes are involved. There are several issues in this regard, however, that affect our interpretation of the results, and should be addressed.

1. The absolute concentration profiles of the antagonists in the spinal cord, particularly in vivo, are unknown. Equilibration between extracellular and bath concentrations of antagonists is facilitated in vitro by the short diffusion distances [phrenic and intercostal motoneuron pools are located from 110-300 $\mu \mathrm{m}$ below the ventral surface in the 0 - to 4 -d-old neonate (Smith et al., 1988a, b)] and the lack of a blood-brain barrier and blood circulation. Kynurenic acid and AP4 were effective in blocking spinal respiratory motor discharge in vitro at bath concentrations similar to those necessary for attenuation of excitatory synaptic transmission in tissue slices (e.g., Cotman et al., 1986) where bath-tissue concentration gradients are further minimized. This suggests that in the present in vitro experiments the antagonists attained extracellular synaptic concentrations close to those in the bathing medium. Furthermore, the concentrations of L-AP4 that inhibited spinal respiratory discharge in vitro is similar to the $K_{d}$ for AP4 binding to rat brain synaptic membranes (1-10 $\mu \mathrm{M}$; Baudry and Lynch, 1981).

Under the present conditions, it was impossible to estimate the concentration of antagonists in the in vivo spinal cord. Relative to the in vitro situation, the greater diffusion distances and presence of blood circulation would significantly steepen the concentration gradient. A steep concentration gradient could account for the greater concentrations of antagonists necessary to produce effects in vivo. Although the results we observed in vivo are consistent with an excitatory amino acid receptor-specific action in the spinal cord and with the in vitro results, further studies with intracellular recording and agonist-antagonist in-
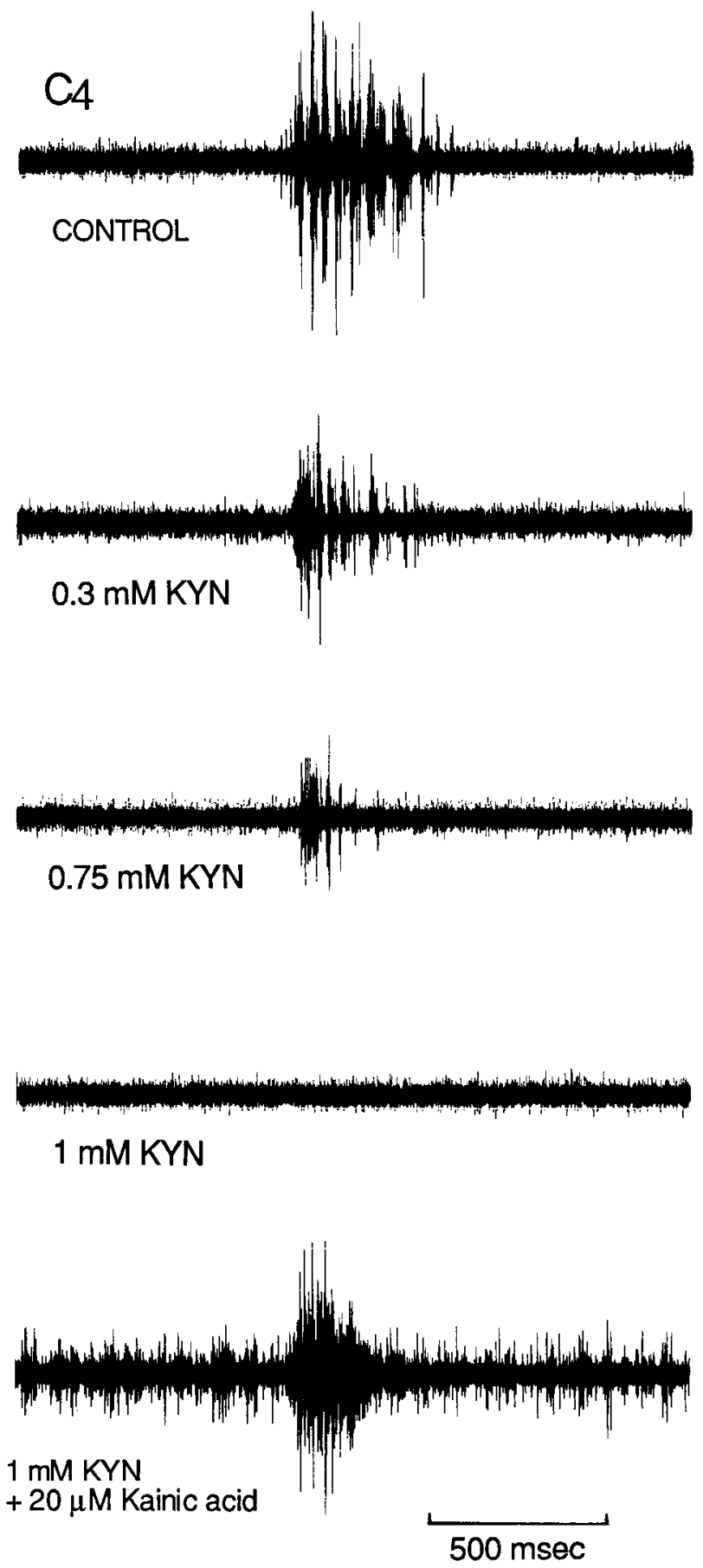

Figure 5. Dose-dependent antagonism of cervical phrenic $\left(C_{4}\right)$ motoneuron discharge in vitro by kynurenic acid (0.3-1 IIIM) applied to spinal cord bath in brain stem-spinal cord preparation with bath partition at spinomedullary junction. Note dose-dependen $\hat{i}$ reduction in both amplitude and duration of cervical ventral root discharge and partial reversal of antagonism by addition of kainic acid $(20 \mu \mathrm{M})$ to spinal cord bath.

teractions will be required to determine the actual mechanisms of antagonist and uptake inhibitor actions.

2. In the case of the dipeptide antagonists DGG and DGT, partial inactivation of these antagonists by endogenous peptidases may have produced concentration gradients. The extent of the involvement of peptidases in vitro is currently unknown. The concentrations of DGG effective in these studies are within 


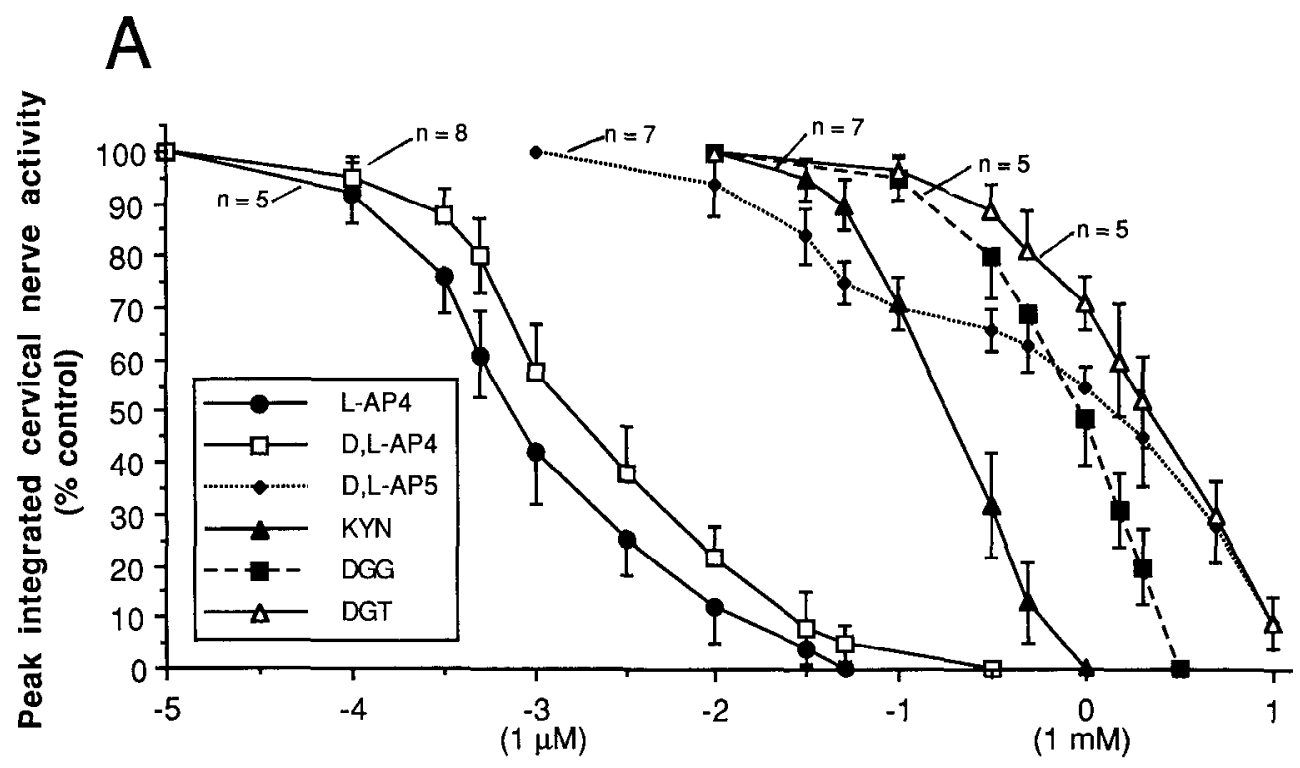

Figure 6. Dose-effect relationships of excitatory amino acid antagonists on motor discharge of $(A)$ cervical ventral roots containing phrenic motoneuron axons and $(B)$ thoracic spinal roots containing intercostal motoneuron axons. Abbreviations: L- and D,L-2-amino-4phosphonobutyric acid, $L$ - and $D, L-$ AP4; D,L-2-amino-5-phosphonovaleric acid, $D, L-A P 5$; kynurenic acid, $K Y N$; $\gamma$-D-glutamylglycine, $D G G ; \gamma$-D-glutamyltaurine, $D G T$. Points and bars: mean values $\pm \mathrm{SD}$.

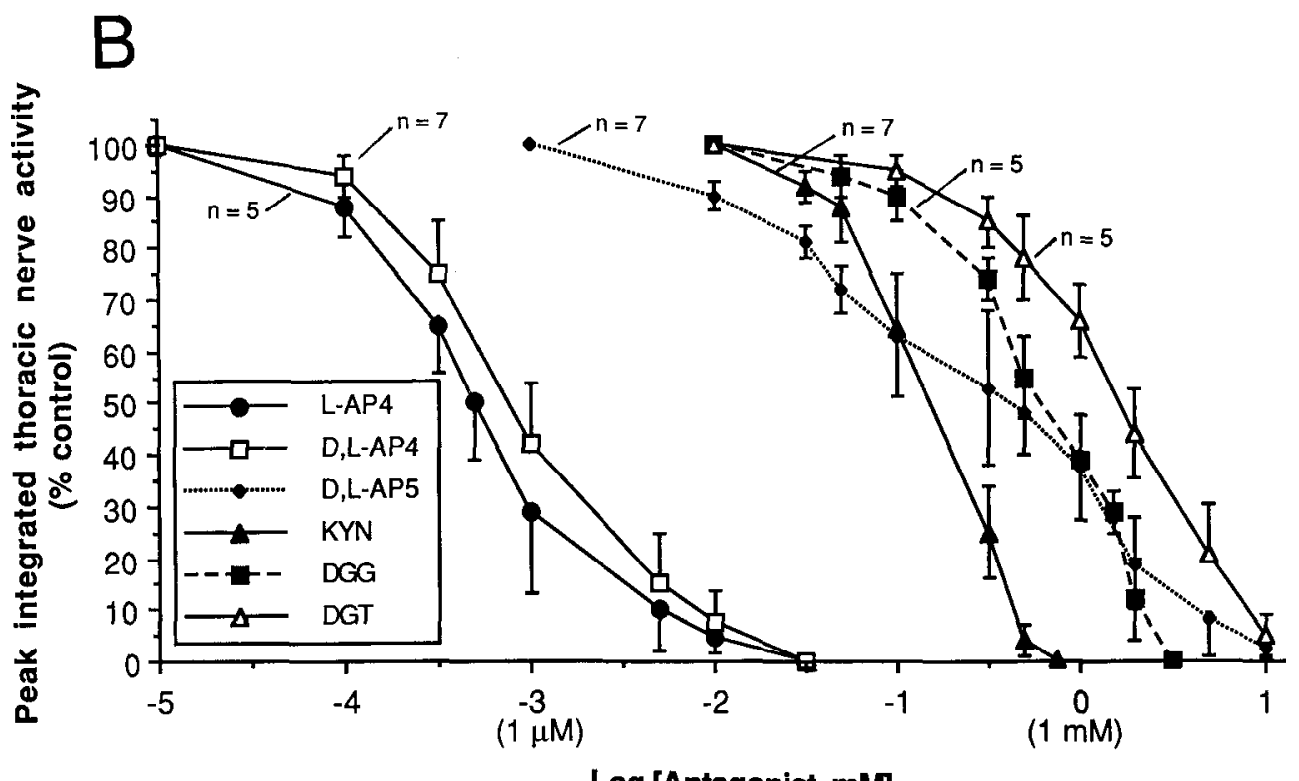

the range effective for antagonism of synaptic responses in other CNS neurons and pathways (Koerner and Cotman, 1982; Rothman and Samaie, 1985).

\section{Role of non-NMDA receptors}

The present results suggest that non-NMDA excitatory amino acid receptors are particularly important in the transmission of spinal respiratory drive. (1) Antagonists at kainic acid, quisqualic acid, and AP4-related receptors could abolish spontaneous respiratory discharge. The high potency and stereoselectivity of L-AP4 in blocking respiratory motor discharge suggests a major role for this receptor subtype. (2) At concentrations expected for NMDA receptor specificity (see below), the selective NMDA receptor antagonist AP5 was much less effective than the other antagonists. (3) Kynurenic acid, an effective antagonist at non-NMDA (and NMDA) receptors blocked the motor discharge at concentrations effective in blocking post- synaptic non-NMDA receptors at other CNS synapses (Cotman et al., 1986; Mayer and Westbrook, 1987; Stone and Burton, 1988). (4) DGG, which antagonizes excitatory amino acid agonist responses in the order NMDA $>\mathrm{KA} \geq$ quisqualate (Jones et al., 1984; Mayer and Westbrook, 1987), with some selectivity for non-NMDA receptors at high concentrations, also significantly reduced the discharge amplitude. DGT, which reputedly shows some selectivity for kainate/quisqualate receptors (Jones et al., 1984), significantly reduced inspiratory motor discharge only at concentrations $>1 \mathrm{mM}$ (Fig. 6), suggesting that significant antagonist action at both NMDA and non-NMDA receptors (see below) may be required for the most effective block of motor activity. However, in recent experiments (Liu et al., 1988) where intracellular recording was used for directly examining antagonist effects on phrenic motoneuron membrane potentials, we have demonstrated block of spinal motoneuron discharge and synaptic drive potentials with low concentrations $(<20 \mu \mathrm{M})$ of 

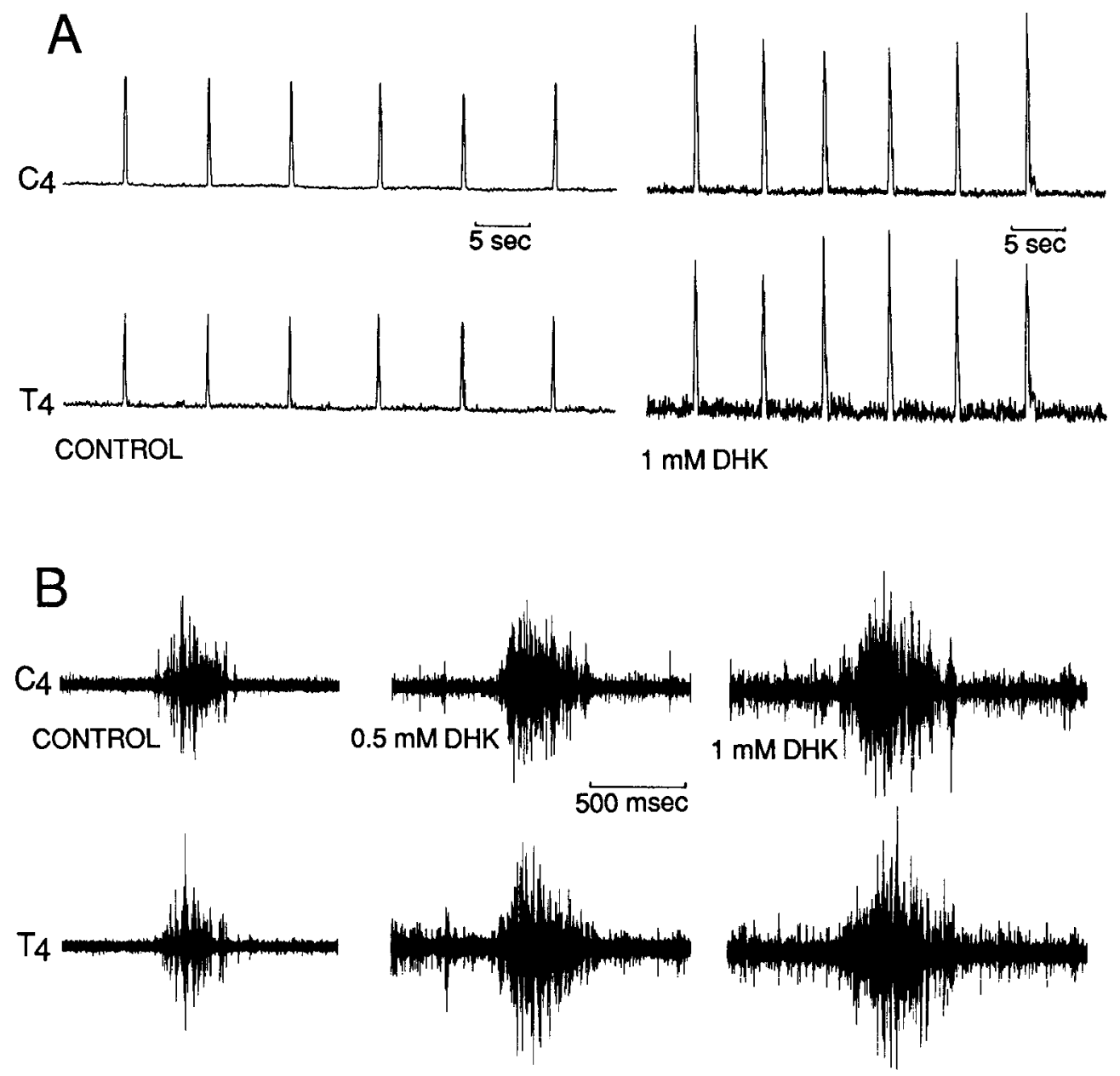

Figure 7. Augmentation of respiratory motor discharge on cervical and thoracic spinal ventral roots with the application of amino acid uptake inhibitor dihydrokainic acid $(D H K)$ to spinal cord bathing solution in vitro. In vitro bath was partitioned at spinomedullary junction. $A$, Traces show integrated $\mathrm{C}_{4}$ and $\mathrm{T}_{4}$ ventral root discharge before (left) and after (right) application of 1 mM DHK. $B$, Recordings of $\mathrm{C}_{4}$ and $\mathrm{T}_{4}$ ventral root discharge illustrating augmentation of discharge with increasing DHK concentration. DHK induces tonic motoneuronal discharge and increases the motor discharge amplitude and duration.

the selective non-NMDA receptor antagonist 6-cyano-7-nitroquinoxaline-2,3-dione (CNQX) (Honore et al., 1988), confirming a major role for non-NMDA receptors.

A more limited involvement of NMD $\Lambda$ receptors is suggested by the following observations. (1) AP5 caused a relatively small reduction in the motor discharge at concentrations $(<100 \mu \mathrm{M})$ expected to be selective for NMDA receptors (Watkins and Evans, 1981; Stone and Burton, 1988). (2) High concentrations of AP5 $(>100 \mu \mathrm{M})$ produce only a small reduction in amplitude of the postsynaptic respiratory drive potential recorded intracellularly from phrenic motoneurons (Feldman et al., 1988). (3) Elevated extracellular $\mathrm{Mg}^{2+}$ (above physiological concentrations of $1 \mathrm{~mm}$ ), which should block postsynaptic NMDA receptors (Mayer and Westbrook, 1987), also produced only a relatively small reduction in the motor discharge amplitude. In fact, the observed reduction of discharge could in part be due to a nonspecific effect of elevated $\mathrm{Mg}^{2+}$, including effects on $\mathrm{Ca}^{2+}$ channels or on membrane surface charge. Furthermore, removal of extracellular $\mathrm{Mg}^{2+}$ did not perturb the motoneuronal discharge, suggesting that the voltage-dependent properties of the NMDA channel caused by endogenous $\mathrm{Mg}^{2+}$ block are not required for maintenance of the motoneuronal discharge. (4) DGG, which at low concentrations blocks NMDA receptors (Mayer and Westbrook, 1987), was most effective in blocking the motor discharge at high concentrations, where kainate and/or quisqualate receptors should also be blocked. There is, however, an action of AP5 at concentrations expected for NMDA receptor specificity; AP5 produces a small reduction in amplitude of both the motoneuronal discharge and the underlying postsynaptic drive potential (Feldman ct al., 1988). The dose-effect relationship for D,L-AP5 is bimodal (Fig. 6), exhibiting an inflection above concentrations expected for specificity, suggesting a change in the antagonist action at higher concentrations; the effects of D,L-AP5 at high concentrations $(>100 \mu \mathrm{M})$ may be due to a depressant action of L-AP5 on synaptic transmission not involving NMDA receptors (Collingridge et al., 1983). The data therefore suggest that a component of the transmission may involve NMDA receptors. Recent studies on excitatory synaptic transmission to spinal motoneurons in the lower vertebrate spinal cord (Dale and Roberts, 1984; Dale and Grillner, 1986) suggest a dual-component postsynaptic excitation consisting of both fast and slow postsynaptic potentials mediated by non-NMDA and NMDA receptors, respectively, perhaps activated by a glutamate-like substance with mixed-agonist actions at both receptor subtypes. The results presented here are consistent with a dualcomponent excitation of spinal respiratory motoneurons, with non-NMDA receptors playing a major role; our current intracellular studies (Feldman et al., 1988; Liu et al., 1988) examining the effects of the antagonists on the motoneuronal synaptic drive potential are also consistent with this conclusion.

The precise location within the spinal cord of the synaptic sites at which the antagonists produced the effects on transmis- 


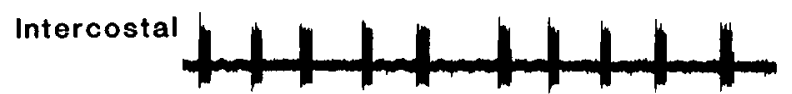

Figure 8. Inhibition of intercostal nerve discharge by $\mathrm{D}, \mathrm{L}-2$-amino-4phosphonobutyric acid $(D, L-A P A)$ applied to juvenile rat spinal cord in vivo. Top left, Control $\mathrm{T}_{8}$ external intercostal nerve discharge and diaphragm EMG. Top right, Five minutes following application of bathing solution containing D,L-AP4 (10 mM in buffered saline, $\mathrm{pH}$ 7.4) to the thoracic spinal cord. External intercostal nerve discharge is blocked with no effect on phrenic nerve discharge and diaphragm EMG amplitude. Small regularly spaced pulses on EMG trace is EKG. Bottom, Recovery of intercostal nerve discharge $10 \mathrm{~min}$ after the cord was washed with buffered normal saline ( $\mathrm{pH} 7.4)$.
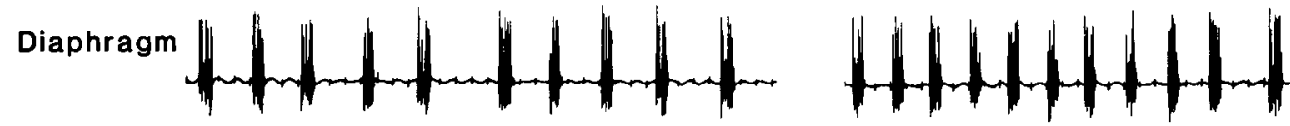

2 sec

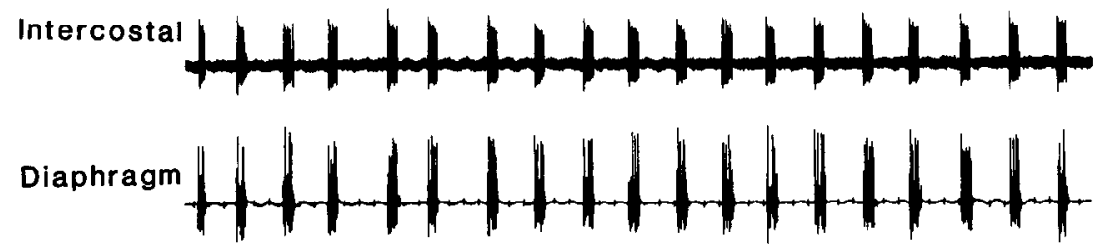

sion of respiratory drive remains to be determined. There is considerable evidence that a major component of the bulbospinal transmission of respiratory drive to phrenic and thoracic motoneurons is monosynaptic (e.g., Hilaire and Monteau, 1976; Feldman and Speck, 1983; Feldman et al., 1985; Duffin and Lipski, 1987; Ellenberger and Feldman, 1988); segmental neurons may also be important in transmission of respiratory drive to thoracic motoneurons (Kirkwood et al., 1988). There is also evidence of a propriospinal relay for descending respiratory drive within the $C_{1}-C_{2}$ spinal segments (Aoki et al., 1987), but the axonal terminations of these propriospinal neurons have not yet been determined. In the present studies, we ruled out a significant involvement of an upper cervical spinal relay in transmission of inspiratory drive by using brain stem-spinal cord preparations with double partitions of the in vitro bath. With partitions at the spinomedullary junction and $T_{1}$ levels, application of high concentrations of kynurenic acid $(1 \mathrm{~mm})$ or $\mathrm{L}-\mathrm{AP} 4(50 \mu \mathrm{M})$ to the central compartment containing the $\mathrm{C}_{1}-$
$\mathrm{C}_{8}$ spinal segments blocked $\mathrm{C}_{4}$ and $\mathrm{C}_{5}$ discharge but did not affect discharge from thoracic motoneuron populations. Application of high concentrations of the antagonists to the central compartment with partitions at the spinomedullary junction and $\mathrm{C}_{3}$ level did not affect the motor activity of either phrenic or cervical motoneuron pools. These results exclude the involvement of an excitatory amino acid-mediated upper cervical relay in the transmission pathway; however, they do not exclude the possibility that there is a transmission pathway through upper cervical propriospinal neurons that is mediated by transmitters other than excitatory amino acids. Furthermore, such experiments also do not rule out polysynaptic transmission via segmental interneurons in the immediate vicinity of the motor nuclei. However, interneurons in the vicinity of phrenic motoneuron pools have not yet been identified, despite extensive recording in the adult mammal, though there is electrophysiological evidence of their presence in thoracic segments (Davies et al., 1985a, b; Kirkwood et al., 1988). The somewhat greater

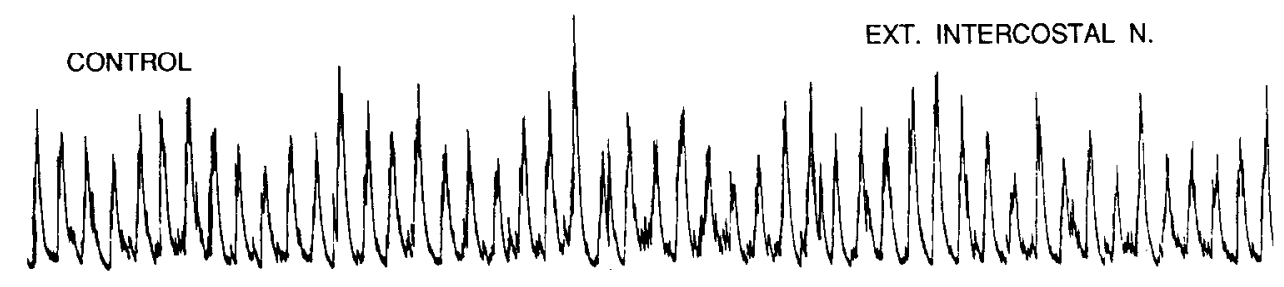

Figure 9. Augmentation of respiratory motoneuronal discharge with application of bathing solution containing amino acid uptake inhibitor glutamate monohydroxamate to thoracic spinal cord (segments $\mathrm{T}_{5}-\mathrm{T}_{13}$ ) of a juvenile rat in vivo. Top, Control motor discharge pattern on $\mathrm{T}_{8}$ external intercostal nerve. Bottom, Motor discharge following application of bathing solution containing $10 \mathrm{~mm}$ glutamate monohydroxamate. Traces are integrated intercostal nerve discharge.

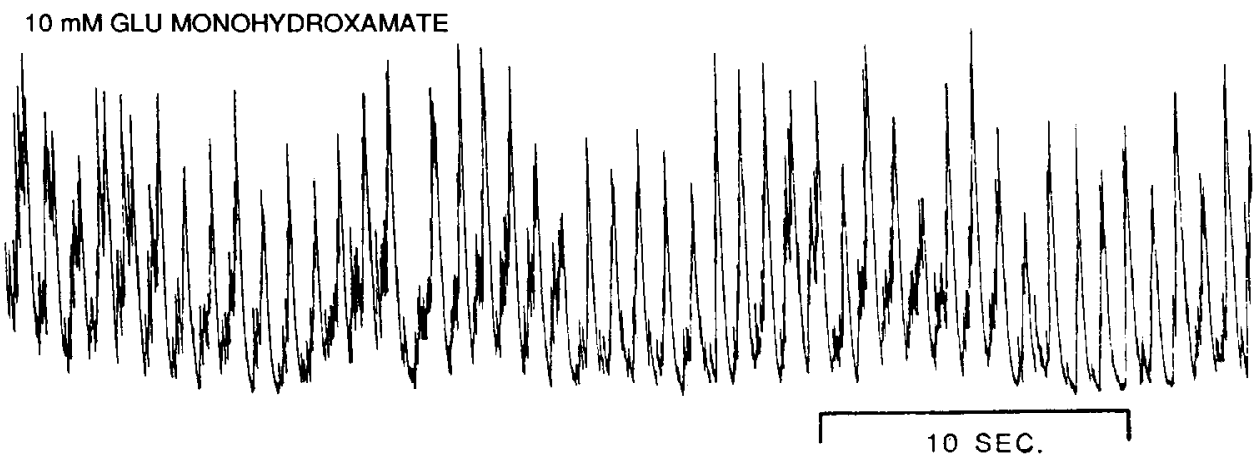


sensitivity of thoracic motoneuron activity to the excitatory amino acid antagonists may be attributable in part to a greater importance of segmental interneurons in transmitting descending respiratory drive to thoracic motoneurons, but see below (Kirkwood et al., 1988).

Even if the antagonists act at synapses on phrenic and intercostal motoneurons, the present studies do not reveal their mechanisms of action. Intracellular recording studies in the mammalian spinal cord in vivo (Jodkowski et al., 1987) and in vitro (Smith et al., 1988a, b) show that the synaptic transmission of inspiratory drive produces a $5-15 \mathrm{mV}$ depolarization of the phrenic motoneuronal somatic potentials, which brings the neuron to threshold for spike initiation. Recording from the motor axons in the present study indirectly measures the effects of the antagonists on neuronal excitability. Recent intracellular recordings from the phrenic motoneurons in the in vitro brain stem-spinal cord preparation (Feldman et al., 1988; Liu et al., 1988; Smith et al., 1988b) indicate that the antagonist concentrations sufficient to completely block spike generation and motor nerve activity produce a small (1-5 mV) dose-dependent reduction in inspiratory drive potential amplitude (e.g., fig. 2 in Smith et al., 1988a, b). The intracellular recordings indicate that $\sim 2$ times higher concentrations of antagonists are required for significant reduction $(>75 \%)$ of the drive potential amplitude; the order of potency of the antagonists, L-AP4 $>$ kynurenic acid $>$ D, L-AP5, in reducing the drive potential amplitude at high antagonist concentrations is the same as reported here for block of spike discharge recorded extracellularly. The greater sensitivity of thoracic motoneuron pools to the antagonists may be due to lower drive potentials in these cells, requiring a smaller relative reduction in the potential amplitude to produce block of spike discharge. The extracellular recording data presented in this study provide information on the involvement of excitatory amino acid receptors in synaptic events near threshold and spike generation, which, from the viewpoint of motor function, is a critical regime of motoneuron behavior; however, the results do not allow us to discriminate between pre- and postsynaptic sites of action, nor do they indicate the details of the subthreshold synaptic phenomena.

Several studies have demonstrated that the AP4 binding site in neural tissue is associated with presynaptic structures (Fagg et al., 1982; Mena et al., 1985; Cotman et al., 1986). The response of the inspiratory bulbospinal pathway to L-AP4 and kynurenic acid found in this study is similar to that of the mossy fiber-CA3 pyramidal neuron excitatory synaptic pathway, where there is evidence for a presynaptic site of action of L-AP4 and a postsynaptic site of action for kynurenic acid in the block of excitatory synaptic transmission (Cotman et al., 1986). Our present results showing a high sensitivity to L-AP4 are consistent with the hypothesis that neurotransmission of bulbospinal inspiratory drive involves endogenous excitatory amino acids acting at AP4-sensitive sites (possibly presynaptic; see note added in proof) and postsynaptic non-NMDA (primarily) and NMDA receptors.

Regardless of whether the primary actions we observed are pre- and/or postsynaptic, the ability of excitatory amino acid antagonists to abolish spontaneous inspiratory motor discharge suggests that endogenous activation of these receptors is an important determinant of the pattern of discharge of spinal inspiratory motoneurons. The enhancement of inspiratory motor discharge by the blockade of amino acid uptake in vivo and in vitro is consistent with such a role and supports the conclusion that the endogenous ligand for these receptors is continually released within the spinal cord. From the data presented here we cannot distinguish whether this ligand is a neurotransmitter released periodically by bursts in bulbospinal inspiratory neurons onto the spinal respiratory motoneurons or propriospinal interneurons, or is released tonically in another pathway that biases the motoneuronal excitability. However, recent studies (Feldman et al., 1988; Liu et al., 1988) indicate that the excitatory amino acid receptor antagonists do not produce significant shifts in the postsynaptic motoneuronal resting membrane potential, and therefore tonic inputs affecting postsynaptic motoneuronal excitability do not appear to be involved. The hypothesis we favor is that excitatory amino acid neurotransmission mediates the monosynaptic bulbospinal inspiratory drive to spinal motoncurons. Since (some) bulbospinal inspiratory neurons have collateral projections within brain-stem regions containing respiratory neurons (Merrill, 1974), this would suggest that synaptic interactions mediated by these axonal collaterals are also mediated by excitatory amino acid neurotransmitters.

The bulbospinal neuron-spinal respiratory motoneuron synapse may provide a convenient model synapse in the spinal cord for detailed analysis of mechanisms underlying excitatory amino acid-mediated synaptic transmission of motor drive. The particular features of this synaptic pathway that facilitate the experimental analysis of mechanisms mediating synaptic transmission include: (1) The availability of an in vitro system to investigate synaptic mechanisms with spontaneously generated synaptic inputs; (2) Well-separated and readily located pre- and postsynaptic neurons; (3) A physiological understanding of the function of the synapse, i.e., the transmission of periodic motor drive; and (4) The presence of amino acid receptor-mediated, as well as (potentially) noradrenergic, serotonergic, GABAergic, and peptidergic, synapses on the postsynaptic cell (Holtman et al., 1984; Charlton and Helke, 1985; Zhan et al., 1987), providing the opportunity for investigation of the interactions of excitatory amino acid-mediated with other transmitter-mediated synaptic mechanisms.

Note added in proof: Intracellular recordings from phrenic mononeurons in vitro, following action potential block by tetrodotoxin, indicate the presence of postsynaptic kainic acid, quisqualic acid, and NMDA receptors (Feldman and Smith, 1989). However, our evidence suggests the absence of postsynaptic AP4 receptor sites that affect the action of excitatory amino acids on phrenic motoneurons. These experiments provide preliminary evidence that AP4 exerts its potent disfacilitatory effects on inspiratory drive transmission at the bulbospinal-phrenic motoneuron synapse by action at a presynaptic receptor (Ibid).

\section{References}

Aoki, M., Y. Fujito, Y. Kurosawa, H. Kawasaki, and I. Kosaka (1987) Descending inputs to the upper cervical inspiratory neurons from the medullary respiratory neurons and the raphe nuclei in the cat. In Respiratory Muscles and Their Neuromotor Control, G. C. Sieck, S. C. Gandevia, and W. E. Cameron, eds., pp. 73-82, Raven, New York. Baudry, M., and G. Lynch (1981) Characterization of two $\left[{ }^{3} \mathrm{H}\right] \mathrm{glutamate}$ binding sites in rat hippocampal membranes. J. Neurochem. 36:811820.

Brodin, L., and S. Grillner (1985) The role of putative excitatory amino acid neurotransmitters in the initiation of locomotion in the lamprey spinal cord. I. The effects of excitatory amino acid antagonists. Brain Res. 360: 139-148.

Charlton, C. G., and C. J. Helke (1985) Autoradiographic localization and characterization of spinal cord substance $P$ binding sites: High 
densities in sensory, autonomic, phrenic, and Onuf's motor nuclei. J. Neurosci. 5: 1653-1661.

Cohen, M. I., M. F. Piercey, P. M. Gootman, and P. Wolotsky (1974) Synaptic connections between medullary inspiratory neurons and phrenic motoneurons as revealed by cross-correlation. Brain Res. 81: 319-324.

Collingridge, G. L., S. J. Kehl, and H. McLennan (1983) The action of an N-methylaspartate antagonist on synaptic processes in the rat hippocampus. J. Physiol. (Lond.) 338: 27P.

Collins, G. G. S. (1982) Some effects of excitatory amino acid receptor antagonists on synaptic transmission in the rat olfactory cortex slice. Brain Res. 244: 311-318.

Colquhoun, D., F. Dreyer, and R. E. Sheridan (1979) The actions of tubocurarine at the frog neuromuscular junction. J. Physiol. (Lond.) 293: 247-284.

Cotman, C. W., J. A. Flatman, A. L. Ganong, and M. W. Perkins (1986) Effects of excitatory amino acid antagonists on evoked and spontaneous excitatory potentials in Guinea-pig hippocampus. J. Physiol. (Lond.) 378: 403-415.

Dale, N. (1986) Excitatory synaptic drive for swimming mediated by amino acid receptors in the lamprey. J. Neurosci. 6: 2662-2675.

Dale, N., and S. Grillner (1986) Dual-component synaptic potentials in the lamprey mediated by excitatory amino acid receptors. J. Neurosci. 6: 2653-2661.

Dale, N., and A. Roberts (1984) Dual-component amino acid-mediated synaptic potentials: Excitatory drive for swimming in Xenopus embryo. J. Physiol. (Lond.) 363: 35-59.

Davies, J. G., and J. C. Watkins (1982) Actions of $D$ and $L$ forms of 2-amino-5-phosphonovalerate and 2-amino-4-phosphonobutyrate in the cat spinal cord. Brain Res. 235: 378-386.

Davies, J. G., P. A. Kirkwood, and T. A. Sears (1985a) The detection of monosynaptic connections from inspiratory bulbospinal neurons to inspiratory motoneurons in the cat. J. Physiol. (Lond.) 368: $33-$ 62.

Davies, J. G., P. A. Kirkwood, and T. A. Sears (1985b) The distribution of monosynaptic connections from inspiratory bulbospinal neurons to inspiratory motoneurons in the cat. J. Physiol. (Lond.) 368: 63-87.

Duffin, J., and J. Lipski (1987) Monosynaptic excitation of thoracic motoneurons by inspiratory neurones of the nucleus tractus solitarius of the cat. J. Physiol. (Lond.) 390: 415-431.

Ellenberger, H. H., and J. L. Feldman (1988) Monosynaptic transmission of respiratory drive to phrenic motoneurons from brainstem bulbospinal neurons in the rat. J. Comp. Neurol. 269: 47-57.

Evans, R. H., A. A. Francis, A. W. Jones, D. A. S. Smith, and J. C. Watkins (1982) The effects of a series of $\omega$-phosphonic $\alpha$-carboxylic amino acids on electrically evoked and excitant amino acid-induced responses in isolated spinal cord preparations. Br. J. Pharmacol. 75: 65-75.

Fagg, G. E., A. C. Foster, E. E. Menna, and C. W. Cotman (1982) Chloride and calcium ions reveal a pharmacologically distinct population of L-glutamate binding sites in synaptic membranes: Correspondence between biochemical and electrophysiological data. J. Neurosci. 2: 958-965.

Fedorko, L., E. M. Merrill, and J. Lipski (1983) Two descending medullary inspiratory pathways to phrenic motoneurons. Neurosci. Lett. 43: 285-291.

Feldman, J. L. (1986) Neurophysiology of breathing in mammals. In Handbook of Physiology, Section 1: The Nervous System, Vol. 4, Intrinsic Regulatory Systems of the Brain, F. E. Bloom, ed., pp. 463524, American Physiological Society, Bethesda, MD.

Feldman, J. L., and J. C. Smith (1989) Cellular mechanisms underlying modulation of breathing pattern in mammals. Ann. NY Acad. Sci. (in press).

Feldman, J. L., and D. F. Speck (1983) Interactions among inspiratory neurons in dorsal and ventral respiratory groups in cat medulla. $J$. Neurophysiol. 49: 472-490.

Feldman, J. L., A. D. Loewy, and D. F. Speck (1985) Projections from the ventral respiratory group to phrenic and intercostal motoneurons in cat: An autoradiographic study. J. Neurosci. $8: 1993-2000$.

Feldman, J. L., G. Liu, and J. C. Smith (1988) Role of excitatory amino acids in transmission of respiratory drive to phrenic motoneurons. II: N-methyl-D-aspartic acid (NMDA) and 2-amino-4-phosphonobutyric acid sensitive $(\Lambda \mathrm{P} 4)$ receptors. Soc. Neurosci. Abstr. 14: 938.
ffrench-Mullen, J. M. H., N. Hori, H. Nakanishi, N. T. Slater, and D. O. Carpenter (1983) Asymmetric distribution of acetylcholine receptors and $\mathrm{M}$ channels on prepyriform neurons. Cell. Mol. Neurobiol. 3: 163-181.

ffrench-Mullen, J. M. H., R. Zaczek, K. Koller, J. T. Coyle, and D. O. Carpenter (1985) N-Acetyl-aspartyl-glutamate: Possible role as the neurotransmitter of the lateral olfactory tract. Proc. Natl. Acad. Sci. USA $82: 3897-3900$.

Foster, A. C., and G. E. Fagg (1984) Acidic amino acid binding sites in mammalian neuronal membranes, their characteristics and relationship to synaptic receptors. Brain Res. Rev. 7: 103-164.

Ganong, A. H., T. H. Lanthorn, and C. W. Cotman (1983) Kynurenic acid inhibits synaptic and acidic amino acid-induced responses in the rat hippocampus and spinal cord. Brain Res. 273: 170-174.

Halliwell, J. J., and P. R. Adams (1982) Voltage-clamp analysis of muscarinic excitation in hippocampal neurons. Brain Res. 250: 7192.

Hilaire, G., and R. Monteau (1976) Connexions entre les neurones inspiratoires bulbaires et les motoneurones phréniques et intercostaux. J. Physiol. (Paris) 72: 987-1000.

Holtman, J. R., Jr., P. N. Wesley, L. Skirboll, K. L. Dretchen, C. Cucllo, T. J. Visser, T. Hökfelt, and R. A. Gillis (1984) Evidence for 5-hydroxytryptamine, substance $\mathrm{P}$, and thyrotropin-releasing hormone in neurons innervating the phrenic motor nucleus. J. Neurosci. 4: 1064-1071.

Honore, T., S. N. Davies, J. Drejer, E. J. Fletcher, P. Jacobsen, D. Lodge, and F. E. Nielsen (1988) Quinoxalinediones: Potent competitive non-NMDA receptor antagonists. Science 241: 701-703.

Hori, N., C. R. Auker, D. J. Braitman, and D. O. Carpenter (1982) Pharmacologic sensitivity of amino acid responses and synaptic activation of in vitro prepyriform neurons. J. Neurophysiol. 48: 12891301 .

Jodkowski, J. S., F. Viana, T. E. Dick, and A. J. Berger (1987) Electrical properties of phrenic motoneurons in cat: Correlation with inspiratory drive. J. Neurophysiol. 58: 105-124.

Jones, A. W., D. A. S. Smith, and J. C. Watkins (1984) Structureactivity relations of dipeptide antagonists of excitatory amino acids. Neuroscience 13: 573-581.

Kirkwood, P. A., J. B. Munson, T. A. Sears, and R. H. Westgaard (1988) Respiratory interneurones in the thoracic spinal cord of the cat. $\mathbf{J}$. Physiol. (Lond.) 395: 161-198.

Koerner, J. F., and C. W. Cotman (1981) Micromolar L-2-amino-4phosphonobutyric acid selectively inhibits perforant path synapses from lateral entorhinal cortex. Brain Res. 216: 192-198.

Koerner, J. F., and C. W. Cotman (1982) Response of Shaffer collateral-CA1 pyramidal cell synapses of the hippocampus to analogues of acidic amino acids. Brain Res. 251: 105-115.

Lipski, J., L. Kubin, and J. Jodkowski (1983) Synaptic action of R $\beta$ neurons on phrenic motoneurons studied with spike-triggered averaging. Brain Res. 288: 105-118.

Liu, G., J. C. Smith, and J. L. Feldman (1988) Role of excitatory amino acids in transmission of respiratory drive to phrenic motoneurons. I. Kainate and quisqualate receptors. Soc. Neurosci. Abstr. 14: 938 .

Loewy, A. D., and H. Burton (1978) Nuclei of the solitary tract: Efferent projections to the lower brain stem and spinal cord of the cat. J. Comp. Neurol. 181: 421-450.

Mayer, M. L., and G. L. Westbrook (1987) The physiology of excitatory amino acids in the vertebrate central nervous system. Prog. Neurobiol. 28: 197-276.

McCrimmon, D. R., and J. L. Feldman (1987) Central nervous system pharmacology of the control of breathing: Excitatory amino acids. In Respiratory Muscles and Their Neuromotor Control, G. C. Sieck, S. C. Gandevia, and W. E. Cameron, eds., pp. 37-48, Raven, New York.

McCrimmon, D. R., J. C. Smith, and J. L. Feldman (1986a) Role of excitatory amino acids in transmitting respiratory drive to spinal motoneurons studied in vitro. Fed. Proc. 45:519.

McCrimmon, D. R., J. C. Smith, H. H. Ellenberger, and J. L. Feldman (1986b) Possible excitatory amino acid mediation of inspiratory synaptic drive to spinal motoneurons in neonatal rat. Soc. Neurosci. Abstr. 12: 387.

Mena, E. E., D. T. Monaghan, S. R. Whittemore, and C. W. Cotman (1985) Cations differentially affect subpopulations of L-glutamate receptors in rat synaptic plasma membranes. Brain Res. 329: 319 322 . 
Merrill, E. G. (1974) Finding a respiratory function for medullary respiratory neurons. In Essays on the Nervous System, R. Bellairs and E. G. Gray, eds., pp. 451-486, Clarendon, Oxford.

Robinson, M. B., K. D. Anderson, and J. F. Koerner (1984) Kynurenic acid as an antagonist of hippocampal excitatory transmission. Brain Res. 309: 119-126.

Rothman, S. M., and M. Samaie (1985) Physiology of excitatory synaptic transmission in cultures of dissociated rat hippocampus. J. Neurophysiol. 54: 701-712.

Slater, N. T., J. A. David, and D. O. Carpenter (1986) Relaxation studies on the interaction of hexamethonium with acetylcholine-receptor channels in Aplysia neurons. Cell. Mol. Neurobiol. 6: 191211.

Smith, J. C., and J. L. Feldman (1985) Motor patterns for respiration and locomotion generated by an in vitro brainstem-spinal cord from neonatal rat. Soc. Neurosci. Abstr. 11: 24.

Smith, J. C., and J. L. Feldman (1987a) In vitro brainstem-spinal cord preparations for study of motor systems for mammalian respiration and locomotion. J. Neurosci. Methods 21: 321-333.

Smith, J. C., and J. L. Feldman (1987b) Central respiratory pattern generation studied in an in vitro mammalian brainstem-spinal cord preparation. In Respiratory Muscles and Their Neuromotor Control, G. C. Sieck, S. C. Gandevia, and W. E. Cameron, eds., pp. 27-36, Raven, New York.

Smith, J. C., J. L. Feldman, and B. J. Schmidt (1988a) Neural mech- anisms generating locomotion studied in mammalian brainstem-spinal cord in vitro. FASEB J. 2: 2283-2288.

Smith, J. C., G. Liu, and J. L. Feldman (1988b) Intracellular recording from phrenic motoneurons receiving respiratory drivc in vitro. Ncurosci. Lett. 88: 27-32.

Stone, T. W., and N. R. Burton (1988) NMDA receptors and ligands in the vertebrate CNS. Prog. Neurobiol. 30:333-368.

Stone, T. W., and J. H. Connick (1985) Quinolinic acid and other kynurenines in the central nervous system. Neuroscience 15: $597-$ 617.

Suzue, T. (1984) Respiratory rhythm generation in the in vitro brain stem-spinal cord preparation of the neonatal rat. J. Physiol. (Lond.) 354: 173-183.

Wallén, P., and S. Grillner (1987) N-Methyl-D-aspartate receptorinduced, inherent oscillatory activity in neurons active during fictive locomotion in the lamprey. J. Neurosci. 7:2745-2755.

Watkins, J. C., and R. H. Evans (1981) Excitatory amino acid transmitters. Annu. Rev. Pharmacol. Toxicol. 21: 165-204.

Yamamoto, C., S. Sawada, and S. Takada (1983) Suppressing action of 2-amino-4-phosphonobutyric acid on mossy fiber-induced excitation in the guinea pig hippocampus. Exp. Brain Res. 51: 128-134.

Zhan, W.-Z., H. H. Ellenberger, and J. L. Feldman (1987) Immunohistochemical labeling of monoaminergic terminals in phrenic nucleus of the rat. Soc. Neurosci. Abstr. 13: 59. 